\title{
The Role of Integrated Interdisciplinary Links in the Study of the Mother Tongue in Primary School
}

\author{
S. M. Yatsyna, V. I. Movchan \\ Cherkasy Bohdan Khmelnytsky National University \\ Corresponding author. E-mail: svt.yatsina@gmail.com, Valya_movchan_@ukr.ne
}

Paper received 03.09.21; Accepted for publication 16.09.21.

https://doi.org/10.31174/SEND-PP2021-256IX100-10

\begin{abstract}
The article focuses on an important problem stipulated by cardinal changes in the theory and practice of training and education of children of primary school age. Its topicality is caused by the implementation of the New Ukrainian School Concept, the essence of which is to change the teaching methods of primary school children bringing them most closely to play activities that is a characteristic feature of mental and physical development of children in primary school age. Purpose. To clarify the importance of interdisciplinary connections and interdisciplinary integration in Ukrainian language lessons in the primary grades of the New Ukrainian School, to outline some aspects of the realization of the essence and importance of this phenomenon. Methods. Analysis of scientific literature on the problem, generalization and systematization of the collected material, modeling of integrated processes. Result. The article focuses on various aspects of the implementation of integrated interdisciplinary links in Ukrainian language lessons, including elements of classes in language and reading, language and mathematics, language and science, language and computer science, lan-guage and art. Due to the fact that the new curriculum for primary school students offers the introduction of such subjects as "I explore the world", "I am in the world", "Environment", "Health Technologies", "Natural Science" having an integrated nature in themselves, it allows the primary school teacher to expand the interdisciplinary links of disciplines studied by younger students. Originality. The article emphasizes that modern scholars propose to distinguish between the con-cepts of the "integrated learning" and "interdisciplinary links", which until recently, were interpreted in the literature as similar phenomena. Based on certain theoretical principles of the integrated and interdisciplinary links, different options for their use in native language lessons in primary school have been proposed.Conclusion. Thus, the teacher should analyze the educational material from the proposed subjects, choose topics that are similar in content and purpose, syn-thesize this material and organically combine educational material.
\end{abstract}

Keywords: primary school; interdisciplinary links; integrated lessons; Ukrainian language and Literature reading lessons.

Formulation of the problem. In connection with the reform of primary and secondary education, the important problem is to teach children to perceive the world around them, to determine their place in it, to determine themselves for adult life.

The concept of the New Ukrainian School directs primary school teacher to form a comprehensively developed personality, to teach pupils to work in teams, to be able to group phenomena, facts, events according to one or some features, to find similar phenomena in various spheres of life, to study every sphere of human activity.

The analysis of the scientific literature makes it possible to state that the introduction of interdisciplinary links into the educational process and the integration of learning content is not a new phenomenon in the domestic education system. A. Aleksiuk, M. Danylov, M. Skatkin, I. Lerner, V. Onyshchuk, V. Palamarchuk and others studied interdisciplinary links as a means of activating educational cognition. However, during the introduction of the updated content of primary education, the State Standard, curricula for grades 1-4 of secondary schools, textbooks and manuals, new subjects have appeared. Therefore, the issues of interdisciplinary links and interdisciplinary integration in the new primary school have become relevant $[1 ; 2]$.

O. Biliaiev, I. Bolshakova, L. Varzatska, T. Donchenko, Y. Koliahin, V. Palamarchuk, O. Savchenko, N. Svetlovska, O. Marynovska and others emphasize the effectiveness of the integration of education content and forms. The importance of information technology in the learning process is emphasized in the works of B. Hershunsky, S.
Davidson, G. Reis, G. Selevka, O. Tykhomyrov and others. The essence of multimedia technologies as technologies of the integrated use of all types of information perception (visual, auditory, graphic, textual) was considered by $\mathrm{T}$. Ahapova, V. Yevdokimov, V. Lutsenko, G. Ponomariova. N. Balaniuk, Y. Hromova, I. Mural, A. Tsyhanok, I. Shyshka, L. Yuhova and others dealt with the issue of informatization in primary education.

The application of interdisciplinary integration becomes the subject of research in pedagogical science.

The aim of the paper is to outline the importance of interdisciplinary links and interdisciplinary integration in the Ukrainian Language lessons in primary grades of the New Ukrainian School, some aspects of realizing the essence and importance of this phenomenon.

Research methods. Analysis of scientific literature on the problem, generalization and systematization of the collected material, modeling of the integrated processes.

Presentation of research material. Interdisciplinary links should be considered as a prerequisite for the methodically correct design and use of the integrated courses. According to the current curricula in grades 1-4, almost half of the learning material is studied in the integrated courses. ("I am in the world", "Art", "Natural Science", "Environment", "Health Technology") [3].

The implementation of interdisciplinary links in the educational process of primary school contributes to the formation of educational and cognitive culture, independence, creative thinking of pupils and provides an intellectual climate of the team. The various activities carried out in 
primary school provide the prerequisites for the integrated content of the lesson, which in turn increases the interest in learning, prevents fatigue of pupils. Interdisciplinary links in their content provide a comprehensive approach to the formation of a comprehensively harmonious personality.

One of the leading ideas of modern education is an integrated approach to the organization of the educational process, which overcomes the contradiction between the infinity of modern information space and the limited human capacity for perception, assimilation, and application of information [4]. In the Pedagogical Dictionary, "learning integration" is interpreted as the selection and integration of educational material from different subjects to study important cross-cutting topics holistically systematically and comprehensively, and to create the integrated content of education, i.e., subjects that would unite knowledge from different fields in a single whole [5]. Integration in education, according to American researchers, is an organization of the process of cognition, in which students can use the knowledge and skills acquired in school, in real life situations [6].

H. Fedortsov defines the interdisciplinary links as a pedagogical category of integration links between objects, phenomena, and processes of reality, which are reflected in the content, forms and methods of the educational process and perform educational, developmental, and pedagogical functions in their organic unity [7]. Therefore, the primary school, provided an integrated approach to learning, directs this feature not only to master the educational material, but also to some extent creates the conditions for students to master the "school of life".

However, according to O. Savchenko, interdisciplinary links and integrated content of the lesson are different didactic concepts. Interdisciplinary links involve the inclusion of questions and tasks from the material of other subjects in the lesson that are important for the study of the topic. The peculiarity of the integrated lesson is that it combines blocks of knowledge from different subjects, subordinated to one topic; pupils are involved in different activities [3].

H. Selevko points out that the integrated lessons can be conducted based on intra-subject, inter-subject and intersystem integration: combined two-, three-, four-subject, immersion lesson, excursion lesson, hiking lesson, travel lesson, etc. Integrated lessons often serve as a continuation of the parallel study of related subjects within one lesson [2].

O. Marynovska notes that integration is a "key" to understanding, a prerequisite for the effective formation of key and subject competencies, pupil's success [8].

It should be emphasized that the organization of education in the New Ukrainian School, considering the integrative processes, provides several components that allow to combine different content of educational material in the structure of the lesson so that the specifics of content components do not lose their main purpose. This is due to the presence of some factors. First, we mean that the primary school teacher is a multi-subject teacher, and the semantic possibilities of each subject are well known to him/her.

A successful condition for the implementation of interdisciplinary integration in primary school is the activity approach, which allows to focus primarily on the development of personality, rather than on knowledge as a result of educational activities. In the modern educational process, the task of primary school teachers is to skillfully use integrated material not only to acquire certain knowledge of subjects, but also to promote the readiness of primary school children to use the information obtained in everyday life. In practice, I. Bolshakova offers a method of organizing interdisciplinary integration of learning content in the following main stages:

introduction of interdisciplinary links in lessons of related disciplines based on reproductive activity and elements of problems;

formulation of interdisciplinary educational problems and independent search for their solution in individual lessons;

systematic problem-based learning based on complex interdisciplinary problems within individual courses; inclusion of first bilateral and then multilateral links between different subjects based on the coordination of teacher's activities;

development of a broad system in the work of teachers who make interdisciplinary links in the content and methods and forms of teaching, including extracurricular activities and expanding the scope of curricula [9].

Some researchers pay attention to certain patterns and reservations in the implementation of integration in the educational process of primary school, namely:

- compliance with the requirements for pupils to master the most important general skills of reading, writing, arithmetic, defined by the curricula;

- use of the principle of accessibility to prevent the emergence of despair in their abilities, in the ability to perform a particular task of multifaceted activities;

- refusal to artificially create integrative connections;

- formation of moral values in the learning process [10].

Analysis of current curricula, study of the experience of methodologists and primary school teachers made it possible to integrate educational material on the Ukrainian language and literary reading with individual subjects.

Grade 1. Literacy - acquaintance with the world around, music, drawing.

Grade 2. Ukrainian Language - reading, Russian language, drawing, acquaintance with the world around, music, ethnography.

Grades 3-4. Reading - Ukrainian language, drawing, science, music, ethnography, ethics [1].

The "Methodological recommendations for teaching subjects in secondary schools in 2016-2017" (Appendix to the letter of the Ministry of Education and Science of Ukraine dated 17.08.2016 № 1/9 - 437) indicate the subjects to be integrated: Ukrainian Language and Fine Arts; Ukrainian Language and Natural Sciences; Reading and Health Basics. Interdisciplinary links are implemented through the integrated lessons. For example, pupils can be asked to perform exercises with media products in Ukrainian Language lessons, considering an integrated approach in the unity of cognitive, developmental, and educational aspects, so that personal development is carried out in parallel with knowledge acquisition. When studying the topic "Apostrophe", we offer two pupils or a group divided into two teams to perform the exercise "Race", created using the program Learning Apps. org. On the screen, a sentence appears with a word with a missing sign (letter); pupils need to read it correctly by inserting the appropriate sign 
(apostrophe) or letter. If it is a teamwork, the team that will answer a larger number of tasks quickly and correctly (the content of the sentences may correspond to the topic studied in the Health Basics or Natural Science lessons) comes to the finish.

Besides, with the help of Learning Apps.org. while studying the topics of syntax, we offer the following exercise: on the screen, we see a picture showing children engaged in various types of entertainment (playing with animals, correspondence in the gadget, dialogue between friends). We know what children are talking about from the sentences in this picture. The task for pupils is to analyze these sentences and identify them for the purpose of expression, to make up their own dialogue on a topic identified on the screen. Such exercises should be performed at the end of the lesson.

A remark of children playing with friends is "Do you know the breed of this dog?" We are establishing an interdisciplinary connection between the Ukrainian Language and Natural Sciences. A remark of children playing in gadgets is "Help me, please, to reach a new level". It combines the elements of a lesson in the Ukrainian Language and Computer Science. A remark of the children who compose the letter is "Still, how good it is to have faithful friends!" allows us to integrate oral and written speech.

Analyzing the current Standard Curricula and the content of textbooks for primary classes in the Ukrainian Language and Literary Reading, we can see that one topic is studied in the Literary Reading lessons (O. Y. Savchenko "Literary Reading" Grade 4 [11], "Beauty of the Earth", and beauty of life" topic) and in the Natural Science lessons ("Diversity of Nature in Ukraine" topic)).

If a literary work is learned in Literary Reading lessons, it can be not read, but listened to in audio recording. It is the way of learning the new text that makes it possible to combine elements of literary reading and language, particularly reading and speaking. It is also advisable to offer an additional task to find and write verbs (nouns, adjectives) from the listened text and explain their role in the text.

In the Ukrainian Language lessons, students should be given the task to compose descriptive texts based on the pictures and musical accompaniment presented by the teacher. It is interesting to combine the Ukrainian Language and Mathematics lessons, asking students to perform the action of subtraction: e.g., from which number we should subtract 20 to get 30 ; write down the result and explain the spelling of the word "fifty". One can build a lesson in the form of a fairy-tale journey through the country of Mathematics (identify stations: attention development, work with the textbook, verbal counting, relay race, interesting secrets).

It is appropriate to use dictations of natural content in the Ukrainian Language lessons, at the same time consolidating knowledge of both the Ukrainian 1LLanguage and Natural Sciences. The textbook for grade 3 (part 2) 'I explore the world' by O. Voloshchenko, O. Kozak, G. Ostapenko [12] contains the story "Stork's Feather".

In the Reading lessons of grade 2 on the topic of "Autumn", students can be asked to draw pictures (autumn themes) with the help of a bright presentation of autumn paintings by famous artists, which will reveal the play of colours and aesthetic tastes of children. It will also be valuable to listen to Tchaikovsky's musical excerpt “Autumn

\section{Song" while drawing.}

While studying L. Hlibov's fable "Swan, Crab, and Pike" (grade 3), we offer younger students to use gadgets to find the weight of a swan, pike, and crab, as well as find out information using a help desk (on the Internet), what the size of a swan is, what a swan lives for, where the bird lives.

As mentioned above, interdisciplinary links in primary school lessons are different from the integrated lessons; however, they are also based on the use of cross-curricular links of the subjects that are taught according to the curriculum by primary schoolchildren. We consider the example of the integrated lesson for Grade 3 pupils that can be built on the basis of the topic of the Ukrainian Language "Text structure". Before the lesson, the teacher asks the pupils to do a little research on the weekends, visiting the Pine Forest, where squirrels live. To do this, the pupils should take walnuts with them. Once they find a comfortable place under a pine tree or somewhere in the meadow, they need to knock on the nuts and watch what happens: who will appear near them, what animals, how they will behave with the nuts. At the beginning of the lesson, the teacher asks the children about the trip to the Pine Forest. Pupils say that squirrels ran to the knock of nuts; in some cases, the squirrels took nuts from the pupils' palms and suddenly disappeared; in other cases, the squirrels taking nuts in their paws, climbed a pine tree and there, perched on a branch, gnawed them. The next stage of the lesson is the introduction of the texts from the textbook on the Ukrainian Language for Grade 3 (M. Vashulenko, O. Melnychaiko, N. Vasylkivska) [13]. The pupils need to read and compare two texts and determine which of them can be included in a Reading Textbook and which in a Natural Science textbook, find the difference between the words of both texts (i.e., the difference between the means of artistic and scientific styles). Two passages are displayed on the screen for comparison.

This squirrel is beautiful. A red-brown coat with a white triangle around the chin suits it very well. Its head is small; black tassels are like ornamentation on its long, small ears. Squirrel's eyes are black and shiny like small beads. The tail is fluffy and even bushy, a little smaller than the squirrel. The squirrel is small and very agile. It has tenacious paws, so it easily jumps from tree to tree. The tail helps it in this. It is a small animal but nice and agile.

II

The squirrel is one of the most beautiful animals of our fauna. Its head is small, round, with a broad forehead; its ears are quite large, standing, with tassels of long hairs. The body is elongated, over $20 \mathrm{~cm}$ long, flexible. The tail is fluffy, densely covered with hair. The length of the tail is almost equal to the length of the body. Paws are tenacious, with sharp curved claws on the toes. The colour of squirrel's fur is quite variable: red-brown, brownish-gray, dark brown. As a decoration of our forests, parks and gardens, the squirrel is taken under protection (Serhiy Korniev).

Having analyzed both passages, the pupils conclude that in the artistic style words with figurative meaning are used, and in the scientific - words with exact, specific meaning. After that, the teacher explains that any text consists of three structural parts (components): the beginning, the main part, the ending, and sets the task to find all these 
three components in the text.

Having mastered the theoretical material, pupils perform various practical tasks. An interesting and appropriate task is to draw a squirrel on a sheet of paper (or paint a stencil of an animal), using its images in photographs prepared by the teacher in advance.

This lesson is integrated because it combines elements of four lessons from the disciplines: Natural Sciences, Literary Reading, Ukrainian Language, Fine Arts. Possibilities of introducing interdisciplinary integration into the educational content of the Ukrainian Language and Literary Reading lessons are quite wide: Literary Reading and Ukrainian Language; Literary Reading and Fine Arts; Literary Reading and Labour Training; Ukrainian Language and Health Basics; Ukrainian Language and Mathematics; Ukrainian Language and Natural Sciences.

Conclusions and prospects. The teacher should analyze learning material from the proposed subjects, choose topics that are similar in content and purpose, synthesize this material and organically link them together. In such lessons, the educational purpose is realized; they are interesting and do not overload children with learning material and impressions.

The following important aspects require further research of such an important aspect as the implementation of internal integrative links between sections of language science, including lexicology and morphology, morphology and syntax, syntax, and stylistics.

\section{REFERENCES}

1. Savchenko, O. (2012). Didactics of Primary Education: a textbook. Kyiv: Hramota. 373 p. [In Ukr.]

2. Selevko, G.K. (2006). Models of Content Integration of Educational Disciplines. Encyclopedia of Educational Technologies: in $2 \mathrm{vol}$. Moscow: Research Institute of Educational Technologies. Vol. 1: 479-488. (Series "Encyclopedia of Educational Technologies") [in Rus.].

3. Savchenko, O. (2017). Interdisciplinary Links as a Resource for Implementing Competence Approach in Literary Reading Lessons. Ukrainian Pedagogical Journal, 2: 48-57 [in Ukr.].

4. Beh I. (2002). Integration as an Educational Perspective. Primary school, 5: 5-6 [in Ukr.].

5. Short Terminological Dictionary of Pedagogy (2004). In S.H. Melnychuk (compiled). Kirovograd. 34 p. [in Ukr.].

6. New Ukrainian School: Guide for Teachers Kyiv ( 2017). Pleiades Publishing House LLC. 206 p. [in Ukr.].

7. Kostiuk, N.T. (1998). Objective Conditionality and Dialectic of Modern Scientific Knowledge Integration. Kyiv: High school. 327 p. [in Ukr.].
8. Marynovska, O. (2014). Integrated Learning: Technological Aspect. Native school, 4-5: 33 [in Ukr.].

9. Bolshakova, I. Peculiarities of Realization of Interdisciplinary Content Integration at lessons in primary school. Retrieved from https://ippo.kubg.edu.ua/wp-content/uploads/2014/05/Болшшакова-IO.pdf. [in Ukr.].

10. New Ukrainian School. Ministry of Education and Science of Ukraine: official site. Retrieved from https://mon.gov.ua/ua/tag/nova-ukrainska-shkola. [in Ukr.].

11. Literary reading: pidruchnyk dlia 4 klasu zagalnoosvitniogo navchalnogo zakladu / O. Y. Savchenko. Kyiv: Osvita, 2019, 192 p. [in Ukr.]

12. I explore the world: pidruchnyk of the integrated course dlia 3 klasu (in 2 parts) / O. Voloshchenko, O. Kozak, G. Ostapenko. Kyiv: Svitoch, 2020, 170 p. [in Ukr.]

13. Ukrainska mova: pidruchnyk dlia 3 klasu / M.V. Vashulenko, O.I. Melnychaiko, N.A. Vasylkivska. Kyiv: Osvita, 2019, 192 p. [in Ukr.] 